ROCZNIKI HUMANISTYCZNE

Tom LXIX, zeszyt 2 - 2021

DOI: https://doi.org/10.18290/rh21692-4

SWIETŁANA MULINA

ALEKSANDR RADIUK

\title{
ШЛЯХТА ЗАПАДНОГО КРАЯ В ПОЛИТИКЕ РОССИЙСКОЙ ИМПЕРИИ ВО ВТОРОЙ ПОЛОВИНЕ ХІХ ВЕКА: ЛЕОПОЛЬД ВАЛИЦКИЙ И ЕГО ИМЕНИЕ ОЗЁРЫ ${ }^{1}$
}

Традиция изучения истории европейского дворянства опиралась на представление о том, что эта социальная группа проявляла активность, главным образом, в своих локальных сообществах. Привязанные к своим земельным владениям, дворяне, участвуя в сеймах, обзаводясь земельными участками, получая очередные титулы при дворах правителей, прежде всего, усиливали позиции семьи и увеличивали возможность своего влияния на местный социум ${ }^{2}$. Стремление понять механизмы взаимодействия дворянских семей и окружающего пространства спровоцировало интерес историков к изучению дворянских усадеб, дворянских гнезд, представляющих собою сложный социально-экономический

СветЛАНА АНАтольевна Мулина [Svetlana Anatol'evna Mulina] - кандидат исторических наук, доцент, старший научный сотрудник Омского государственного университета им. Ф.М. Достоевского; адрес для корреспонденции: 644077, Россия, Омск, пр. Мира, 55 a; e-mail: swetmulina@rambler.ru; ORCID: https://orcid.org/0000-0002-4149-0291.

АЛЕКСАНДР ГРИГОРЬЕВИЧ РАДЮК [ALEKSANDR GRIGOR'EVICH RADIUK] - кандидат исторических наук, доцент Европейского гуманитарного университета; адрес для корреспонденции: 230011 Беларусь, Гродно, ул. Курбатова, д. 7; e-mail: radzjuk@gmail.com; ORCID: https://orcid.org/0000-0001-5148-2642.

${ }^{1}$ Работа выполнена при финансовой поддержке РФФИ, проект 17-21-01006 «Разделенные восстанием 1863 года: Сибирь в семейной истории шляхетства Западного края».

${ }^{2}$ W. STRZYŻEWSKI, „Wstęp”, w Szlachta europejska w strukturach lokalnych XVI-XVIII wieku, red. nauk. M. Konopnicka, J. Kuczer, W. Strzyżewski (Zielona Góra: Oficyna Wydawnicza Uniwersytetu Zielonogórskiego, 2010), 7. 
организм $^{3}$, а также культурное явление, совокупность родственных и социальных связей ${ }^{4}$.

Статус, материальное положение, деятельность дворянства во многом определялись политикой властей по отношению к этому сословию. При этом, с одной стороны, государство стремилось к унификации правового положения представителей этого сословия вне зависимости от национальной и религиозной принадлежности, a, с другой, само же эти различия создавало. Ярким примером такой непоследовательной политики являются западные губернии Российской империи, которые в документах того времени часто именовались Западным краем. Для иллюстрации зигзагов политики царизма по отношению к привилегированному сословию этого региона как нельзя лучше подходит судьба помещика Гродненской губернии Леопольда Валицкого. Несмотря на уникальность жизненного пути Леопольда, его опыт был во многом типичен для значительной части представителей дворянского сословия Западного края второй половины XIX в.

Валицкие герба «Лада» относятся к числу довольно разветвленных мелкопоместных шляхетских родов белорусских земель. Однако, некоторым представителям этого семейства удалось оставить значительный след в политической, экономической и культурной жизни всего белорусско-литовского региона. К таким незаурядным представителям данной фамилии, в первую очередь, следует отнести Михаила Валицкого, сколотившего огромное состояние за границей. О происхождении его богатства ходили легенды. Утверждали, что «шулер высокого полета» был одним из доверенных лиц французской королевы Марии-Антуанетты, а состояние сколотил игрой в карты и бильярд 5 . Его земляк Фёдор Булгарин, пересекавшийся с ним в Санкт-Петербурге, высказал предположение, что М. Валицкому удалось разбогатеть на торговле драгоценными

\footnotetext{
${ }^{3}$ НАПРИмеР, см.: А.М. АНФИмОВ, Крупное помещичье хозяйство Европейской России (конеи ХІХ-начале XX века) (Москва: «Изд-во Наука», 1969).

${ }^{4}$ НАПРИМЕР, см.: П. РУзВЕЛЬт, Жизнь в русской усадьбе: опьыт социальной и культурной истории, пер. с англ. Н.А. Вознесенского, А.В. Вознесенского (СПб.: Коло, 2008).

${ }_{5}^{5}$ С.В. ЗАНЕВСКий, „Шляхетский род Валицких в истории Гродно”, в Гродна $і$ гродзенцы: дзевячь стагоддзяу гісторыі (да 880-годдзя горада): матэрыялы Міжнар. навук. канф., Гродна, 10-11 крас. 2008 г., навук. рэд. І.П. Крэнь (Гродна: ГрДУ, 2008), 420-425; А.Ф. САмУСІК, „Граф Міхал Валіцкі - айчынны калекцыянер і мецэнат другой паловы XVIII - першай чвэрці XIX ст.”, в Гродна і гродзенщъы, 416-420.
} 
камнями и картинами ${ }^{6}$. Что не вызывает сомнений, так это факт того, что Михаил действительно обладал богатой ювелирной коллекцией, жемчужиной которой являлся уникальный сапфир, ставший героем повести классика французского сентиментального романа графини де Жанлис 7 .

Несмотря на многочисленные толки в обществе, источник богатств М. Валицкого так и остался неразгаданным. Зато документально известно, как новоиспеченный граф (этот титул он приобрел в Италии) распорядился своим капиталом. По возвращению на родину в 1801 г. он приобретает обширное имение с центром в местечке Озёры ${ }^{8}$ Гродненской губернии. Примечательно, что буквально за несколько лет до этого, 12 ноября 1796 г., это земельное владение было подарено российскому сановнику графу Александру Николаевичу Самойлову ${ }^{9}$. Подобная практика была достаточно распространенной во времена Екатерины II и Павла I, которые с удовольствием и в значительном количестве раздавали лицам, приближенным к престолу, конфискованные на присоединенных после разделов Речи Посполитой территориях имения и королевские экономии. Одной из сопутствующих задач, которая при этом решалась самодержавием, было насаждение русского землевладения на новоприсоединенных территориях. Однако, как показало дальнейшее развитие событий, новых владельцев эти приобретения мало интересовали. Чаще всего они монетизировали их путем скорейшей продажи. В качестве покупателей в таких случаях выступали местные «польские» паны.

Именно таким образом бывшая королевская экономия с местечком Озёры 7 декабря 1801 г. перешла в руки Михаила Валицкого. В результате сделки граф А.Н. Самойлов должен был получить 371165 руб. ${ }^{10}$, а граф Валицкий - обширные владения, состоявшие из нескольких частей (ключей) и занимавшие почти половину всего Гродненского уезда. Это были богатые природными ресурсами угодья, с десятками деревень и несколькими местечками. Принимая во внимание сумму сделки, можно предположить, что русский граф так ни разу их и не наведал. Земли продавались им, исходя из количества крепостных душ, которых по инвентарям насчитывалось 3907, и каждая из них оцени-

\footnotetext{
${ }^{6}$ Ф. БУлГАРИн, Воспоминания Фаддея Булгарина. Отрывки из виденного, сльиманного и испытанного в жизни, [в 6 ч.], ч. 1-2 (СПб.: тип. Эдуарда Праца, 1846), 97.

${ }^{7}$ S.F. DE GENLIS, Cudowny szafir czyli Talizman szczęścia: powiastka wschodnia, przeł. i oprac. J. Raźny, aneksem opatrzył W. Pusz (Łódź: Oficyna Wydawnicza Tercja, 2008).

${ }^{8}$ Встречается различное написание этого топонима: Озёры, Озёра, Азёры, Езиоры.

${ }^{9}$ Lietuvos valstybès istorijos archyvas (LVIA), f. 1219, ap. 1, b. 687, 1. 5.

${ }^{10}$ Гродненские губернские ведомости. Часть неофициальная № 34 (25 августа 1906 г.): 7.
} 
валась в 95 руб. Все остальное имущество было лишь неким атрибутом, который прилагался к крепостным: строения, мельницы, посевы, запасы хлеба, скот, домашняя птица, покосы, озера и другие угодья ${ }^{11}$.

После покупки граф Валицкий оставил себе только одну, центральную часть всех этих обширных угодий, продав все остальное. С имением Озёры тесно переплелась последующая судьба рода Валицких. Михаил и его наследники превратили имение в настоящее родовое гнездо. В первой четверти XIX в. в Озёрах закладывается усадьба с ландшафтным парком, боскетом и аллеями. Помещичий дом был вместилищем картин различных известных европейских мастеров, богатейшей библиотеки, коллекции драгоценных камней, редчайших табакерок, изделий из мрамора и фарфора, а также монет ${ }^{12}$. При этом, в отличие от других подобных семейных собраний, хранящихся за закрытыми дверями, Валицкие, по воспоминаниям современников, были всегда рады продемонстрировать их любому желающему ${ }^{13}$.

Большое влияние Валицкие уделяли упрочнению экономической базы их благосостояния. Для этих целей Михаилом в Озёрах были основаны суконная и бумажная мануфактуры, которые сдавались в аренду прусским мастерам ${ }^{14}$. В хозяйстве имелись винокуренные предприятия и пивоварня, действовали две мельницы и два кирпичных завода. Имение активно торговало лесом и рыбой. Для улучшения коммуникации по инициативе Валицких строится дамба между озёрами Белое и Рыбница, которая служит до настоящего времени. Однако основой финансового благосостояния помещиков все же являлось сельское хозяйство. Уже в первой половине XIX в. в имении активно внедрялись и использовались передовые технологии и методы ведения хозяйства, в том числе английские чугунные молотилки и сечкарни на конской силе. Поскольку в местечке действовало суконное предприятие, помещики разводили испанских тонкорунных овец (до 1000 голов), также заботились

\footnotetext{
${ }^{11}$ Гродненские губернские ведомости, 7.

12 А.Т. ФЕдорук, Старинные усадьбы Гродненщины: Берестовиикий район, Волковысский район, Вороновский район, Гродненский район, Дятловский район, Зельвенский район, Ивьевский район (Минск, 2014), 335; LVIA, f. 378, ap. 1865 p/s, b. 630, 1. 19.

${ }^{13}$ Wspomnienia. Nowogródek, więzienie - wygnanie, przez Edwarda Pawłowicza (Lwów: Drukarnia E. Winiarza, 1887), 79.

${ }^{14}$ I. СоРкІнА, Мястэчкі Беларусі ў канцы XVIII - першай палове XIX cm. (Вільня: Еўрапейскі гуманітарны універсітэт, 2010), 161.
} 
о создании породистого молочного стада, которое состояло из голландских и швейцарских коров ${ }^{15}$.

Как подобает просвещенной элите того времени, Валицкие часть своих доходов жертвовали на благотворительность. Среди прочего это проявилось в передаче Михаилом Виленскому университету части минералогической коллекции и других редких вещей ${ }^{16}$. В 1808 г. он завещал часть доходов со своего имения на воспитание в виленских учебных заведениях восьми бедных дворянских детей ${ }^{17}$. Выплата стипендий продолжалась и после смерти М. Валицкого, даже после ликвидации самого университета в 1831 г. фундуш тогда перешел в пользование Виленского дворянского института.

На деньги Валицких в первой половине XIX в. осуществляется капитальный ремонт православной церкви в местечке Озёры. Каждый год определенная денежная сумма выплачивалась ими в фонд Гродненского благотворительного общества, финансовая поддержка в виде аннуатного платежа оказывалась местному католическому костелу. Таким образом, можно констатировать, что в первой половине XIX в. владельцы Озёр начинают играть значимую социально-экономическую и культурную роль в жизни всего региона.

Основатель озёрской династии Михаил Валицкий умер бездетным. По духовному завещанию от 12 июля 1827 г. он отказал все имение своим племянникам, поэтому после его смерти владельцем Озёр становится Корнелий Валицкий - сын родного брата Михаила, тоже Корнелия ${ }^{18}$. Известно, что в 1812 г. он, как и большинство местной шляхты, поддержал Наполеона, во всех официальных бумагах именовался подполковником и кавалером Мальтийского креста, однако, в отличие от своего дяди, особого следа в истории не оставил. После смерти Корнелия 27 октября 1847 г. имение переходит в собственность его двоюродного брата и, соответственно, еще одного племянника графа М. Валицкого Леопольда.

О ранних годах жизни Леопольда известно немного. Следует отметить, что он не являлся местным уроженцем, появившись на свет в Дисненском

\footnotetext{
${ }^{15}$ Национальный исторический архив Беларуси в г. Гродно (НИАБ в г. Гродно), ф. 96, оп. 1 , д. 65 , л. 89-90.

${ }^{16}$ А.Ф. САмУСІК, „Граф Міхал Валицкі”, 418.

17 Журнал Министерства народного просвещения, шестое десятилетие, ч. CСXLVIII, СПб. 1886, ноябрь, 3.

${ }^{18}$ НИАБ в г. Гродно, ф. 332, оп. 3, д. 1, л. 17-18.
} 
уезде Минской губернии в 1808 году (крещен 27 декабря). Примечательно, что его отец Ян являлся капитанам российской армии и, возможно, принимал участие в войне 1812 г. против Наполеона и, соответственно, против своего племянника Корнелия, о котором речь шла выше. Мать Тереза происходила из рода Сальмонович. Как и большинство уроженцев белорусско-литовского региона привилегированного сословия, своё образование Леопольд получил в Вильно. Вначале это была губернская гимназия, а потом Виленский университет. Важно отметить, что его фамилия не фигурирует ни в одном из списков членов тайных обществ, которые существовали в стенах этого учебного заведения в 20-е годы XIX в. Также Леопольд не принимал участия в восстании $1830-1831$ гг. ${ }^{19}$, за активную поддержку которого студенческой молодежью, университет был закрыт.

В биографии Л. Валицкого полно загадок, причем некоторые из них так и остались без ответа. Первая из них, как это ни странно, касается образования Леопольда. Дело в том, что в источниках того времени существуют нестыковки относительно области его научной квалификации. Так, в одних документах он фигурирует как кандидат философии ${ }^{20}$, в других - права ${ }^{21}$, а в статейном списке имеется запись о том, что он «получил степень кандидата по нравственно-политическому отделению» ${ }^{22}$.

Не совсем понятно, почему именно Леопольду перешло имение Озёры, ведь у Корнелия оставался родной брат Станислав - помещик Кобринского уезда. Кроме того, в октябре 1847 г., когда скончался Корнелий, был еще жив Михаил Валицкий - родной брат Леопольда. Можно лишь допустить, что Михаил, умерший в Гродно 14 сентября 1848 г., в то время был уже болен и отказался от имения в обмен на обещание Леопольда заботиться о его жене Леокадии (из рода Чеховских) и трех дочерях: Марии, Терезе и Людвиге. После вступления Леопольда в имущественные права, семья Михаила постоянно проживала в имении и, как можно предположить, пользовалась его благами и материальными доходами ${ }^{23}$.

Третья загадка связана с профессиональной деятельностью Л. Валицкого. Известно, что до вступления в права владения, он был мелким клерком. Вначале местом его работы являлась канцелярия Виленского

\footnotetext{
${ }^{19}$ НИАБ в г. Гродно, ф. 1, оп. 4, д. 123, л. 2.

${ }^{20}$ НИАБ в г. Гродно, ф. 1 , оп. 4 , д. 123, л. 1.

${ }^{21}$ НИАБ в г. Гродно, ф. 332, оп. 3 , д. 1, л. 17.

${ }^{22}$ НИАБ в г. Гродно, ф. 2, оп. 4, д. 1678, л. 2.

${ }^{23}$ НИАБ в г. Гродно, ф. 1, оп. 29, д. 108, л. 5.
} 
университета, а позже Гродненское депутатское собрание, где он получил чин титулярного советника. Подобная модель поведения была вполне характерна для местной малоземельной и безземельной шляхты. Однако, занятие Леопольдом должности писца в этом же собрании в 1849 г. $^{24}$, т.е. после того, как он стал законным владельцем Озёр, не поддаётся логическому объяснению.

Еще больше вопросов вызывает так называемое дело «о расхищении разными лицами сокровищ, оставшихся после смерти Корнелия Валицкого». В 1855 году (т.е. по прошествии почти 8 лет!) Леопольдом было инициировано уголовное разбирательство по обвинению некоторых особ в том, что они в день смерти его двоюродного брата выкрали значительную часть семейных «несметных богатств» ${ }^{25}$. Для разбора этого дела была создана официальная комиссия, в состав которой вошли чиновники губернской администрации и жандармские чины. Примечательно, что следствие велось не в самом губернском городе, а в одной из усадеб Валицких, а именно в Задубье. Тут же под замко́м или под строгим надзором с запретом куда-либо отлучаться находились подследственные. Как можно судить, Леопольд непосредственно оказывал влияние на работу комиссии.

Неизвестно, чем бы закончилось разбирательство, если бы не вмешательство вышестоящих органов. После нескольких жалоб из Пруссии дело взял под свой личный контроль виленский генерал-губернатор Илья Гаврилович Бибиков. По его приказу все бумаги комиссии были отобраны жандармским офицером и доставлены в Вильно. Здесь генерал-губернатор единолично принимает решение приостановить следствие, поскольку оное, с его точки зрения, «производится совершенно пристрастно, с крайними отступлениями от законного порядка, оговоренные доносителями лица привлекаются к ответственности и подвергаются арестам без всяких правильных оснований» ${ }^{26}$. В итоге виновным был признан сам Л. Валицкий, который согласно предписанию И.Г. Бибикова (или возможно его приемника Владимира Ивановича Назимова) был отдан под полицейский надзор в Гродно с запрещением выезжать за границы этого города, в том числе и в свое имение. Примечательно, что, когда в 1856 г. местное начальство попробовало вновь разобраться в этом деле, показания крестьян имения разделились: часть

${ }^{24}$ НИАБ в г. Гродно, ф. 2 , оп. 4, д. 1678, л. 1.

${ }^{25}$ НИАБ в г. Гродно, ф. 1, оп. 28, д. 655, л. 46

${ }^{26}$ НИАБ в г. Гродно, ф. 1, оп. 5, д. 1666, л. 66. 
из них утверждала, что они были вынуждены лжесвидетельствовать под угрозой наказания со стороны помещика, другие продолжали настаивать на том, что разграбление имущества действительно имело место ${ }^{27}$.

Помимо сведений исключительно официального характера, для понимания Леопольда Валицкого как личности, с нашей точки зрения, важное значение имеют две характеристики, данные ему местными чиновниками с разницей в восемь лет. В 1848 г. губернский секретарь Разводовский свидетельствовал, что Леопольд Валицкий

поведения хорошего, добродушен, но флегматического свойства, которое, как он объяснил мне на сделанное ему замечание, есть следствие скрывающейся в нем болезни, [...] при том и ежедневные его занятия по обширному хозяйству делают его нередко задумчивым; он роста среднего, лицом некрасив, на правый глаз кос и носит бакенбарды с небольшой бородкой ${ }^{28}$.

Из личных бесед с графом Разводовский выяснил, что Валицкий считает необходимым, чтобы помещичьим крестьянам была дарована свобода на правах обязанных крестьян; но свои обязанности как помещик выполняет точно, в связях с подозрительными лицами не замечен, водит знакомства, сообразно своему состоянию и образованию, с высшим кругом общества как Гродно, так и всей губернии ${ }^{29}$.

Что же касается второй характеристики, то она была дана Леопольду в 1856 г. инспектором гродненской врачебной управы К. Забелло в виде медицинского заключения. Согласно этому документу Л. Валицкий,

имеющий от роду 43 лет страдает три года колтуном на голове и разными от оного припадками, а в особенности болью головы, шумом в ушах, ломотою в верхних и нижних конечностях, каковые страдания в нынешнем году усилились; то для получения облегчения в оных, требует г. Леопольд Валицкий отправиться в Друскеники, для употребления тамошних минеральных ванн $[\ldots]^{30}$.

\footnotetext{
${ }^{27}$ НИАБ в г. Гродно, ф. 1, оп. 5, д. 1798.

${ }^{28}$ НИАБ в г. Гродно, ф. 1, оп. 29, д. 108, л. 3 об. В историческом музее Варшавы хранится фотография с подписью «Hr. Walicki», на ней изображен мужчина с бородой и усами, со скрещенными на коленях ладонями. Вероятно, это Леопольд Валицкий, Powstanie styczniowe i zestańcy syberyjscy. Katalog fotografii ze zbiorów Muzeum Historycznego m.st. Warszawy. Część II. Zesłańcy syberyjscy, oprac. E. Kamińska (Warszawa: Muzeum Historyczne m.st. Warszawy, 2005), 49.

${ }^{29}$ НИАБ в г. Гродно, ф. 1, оп. 29, д. 108, л. 5.

${ }^{30}$ НИАБ в г. Гродно, ф. 1, оп. 28, д. 655 , л. 61.
} 
Вследствие слабого здоровья или особенностей характера, но Леопольд так и не завел семьи. Большую часть времени он занимался хозяйством. Охотно экспериментировал: устанавливал градоотводы, ввел многопольную систему хлебопашества, на песчаных местах, где едва росла трава, удобрял поля черноземом из болот, в результате чего земля на протяжении нескольких лет давала прекрасный урожай. Именно Л. Валицкому принадлежит слава первопроходца в деле гибридного скрещивания зубров с коровами. Его опыты в этой сфере имели большой научный резонанс в Европе, а некоторые из них не могут повторить современные учёные ${ }^{31}$.

По свидетельству современников Леопольд Валицкий был «образцовый хозяин» ${ }^{32}$. И действительно, благодаря его усилиям имение Озёры было доведено до «цветущего состояния» ${ }^{33}$. Однако, в середине 60-х годов выявилось, что последнее было обременено долгами и довольно значительными, превышавшими даже его рыночную стоимость. Сегодня мы можем только строить догадки о том, были ли это трудности временного или перманентного характера, или их не было вовсе. О дальнейших перспективах Озёр и его владельца можно говорить только в условном наклонении, поскольку вся их предыдущая логика развития была перечеркнута событиями 1863 г.

Эта дата стала переломной в судьбе не только Л. Валицкого и его имения, но и в судьбах всего края. Новый виленский генерал-губернатор Михаил Николаевич Муравьёв проводил жёсткую репрессивную политику по отношению к привилегированному сословию подчиненных ему территорий. Тысячи его представителей были высланы из края без суда и, фактически, без следствия. При этом непосредственная причастность к национально-освободительной борьбе во многих случаях не являлась обязательным условиям для привлечения к ответственности. В результате реализации целого комплекса мероприятий репрессивного характера пострадало множество ни в чем не повинных людей, в первую очередь, представителей местной шляхты, в которой М.Н. Муравьев видел главного врага российского самодержавия на этих землях.

${ }^{31}$ P. DASZKiEwicz, T. SAMOJLIK, M. KrasińSKA, „Leopold Walicki's Experiments on CrossBreeding European Bison with Cattle in the Context of $19^{\text {th }}$ century Biological Sciences", Историко-биологические исследования 4, № 1 (2012): 33-40.

${ }^{32}$ Pamiętnik wygnańca z roku 1863, spisał z własnych przeżyć (Lucjan) Zawistowski, tekst oprac., wstępem i przypisami opatrzyli W. i M. Wójcikowie, przedmowa W. Caban (Kielce: Instytut Filologii Polskiej Uniwersytetu Jana Kochanowskiego w Kielcach, 2015), 7.

${ }^{33}$ НИАБ в г. Гродно, ф. 1, оп. 29, д. 108, л. 3. 
Весной 1863 г. в лесах неподалеку от Озёр сформировался и начал активную деятельность повстанческий отряд под командованием полковника Александра Ленкевича. В ночь с 1-го на 2-го мая он вместе с 36 повстанцами занял местечко. Главной его целью являлось оружие, которое хранилось на квартире лесничего. Попутно отряд «забрал в имении графа Валицкого несколько лошадей и провизию» ${ }^{34}$. Данный эпизод предопределил будущее имения и его владельца. Леопольд был обвинен в связи с «бунтовщиками» и на основании конфирмации М.Н. Муравьева выслан на поселение в «наиболее отдаленные места Сибири» с лишением прав состояния и конфискацией имущества ${ }^{35}$. К сожалению, нам не удалось выявить военно-следственное дело Л. Валицкого. На основании других подобных разбирательств можно предположить, что владелец Озёр, вероятнее всего, был обвинен в оказании помощи повстанцам. При этом нельзя исключать, что дело было сфабриковано местной военной властью. Подобная практика была достаточно распространена в то время.

Одновременно с арестом Л. Валицкого на его имение был наложен секвестр, а в 1864 г. оно уже фигурирует в списке конфискованных. В соответствующей ведомости от 18 августа 1864 г. значилось, что отобранию в казну подверглось имение Озёры с фольварками: Задубье, Дунаевка, Губинка, Виляново, Козел, Азет и фермами: Элертовщизна и Каменный грод. В имении господская земля (2088 десятин) ежегодно приносила доход 2878 рублей. Крестьянские земли составляли 3932 десятин, леса - 5014 десятин. Всего имение давало ежегодный доход ежегодный доход 10559 руб. 44 коп. 10559 руб. 44 коп. Оброчные статьи составляли: рыбная ловля на озёрах с ежегодным доходом в 1400 руб., водяная мельница - 500 руб., ветряная мельница - 50 руб., винокуренный завод в Задубье - 1000 руб., таковой же в Вилянове - 700 руб., пивоваренный завод - 600 руб., здание для суконной фабрики - 333 руб., питейные дома - 774 руб., молочный скот - 590 руб., лесные покосы - 792 руб., часть пахотной земли, отдаваемой в наем - 216 руб. 5 коп., сады и огороды - 165 руб., пчеловодство - 48 руб. 50 коп., чинш с земель в мест. Озёры - 212 руб. 44 коп., ферма Элертовщизна - 100 руб., ферма Каменный грод - 50 руб., 6 домов в местечке Озёры -83 руб., пастбища -67 руб. ${ }^{36}$

\footnotetext{
${ }^{34}$ НИАБ в г. Гродно, ф. 1, оп. 34, д. 3420, л. 9.

${ }^{35}$ Государственный архив Российской Федерации (ГА РФ), ф. 109, 1 эксп., 1863, оп. 23, д. 416, л. 60 (Информация предоставлена Анной Брус).

${ }^{36}$ НИАБ в г. Гродно, ф. 1, оп. 22, д. 1456, л. 125 об., 127.
} 
Конфискация Озёр стала ярчайшим примером злоупотреблений, беззакония, неприкрытого воровства и хищений со стороны царских властей. В этом конкретном эпизоде, как в зеркале, нашли свое отражение все пороки политики виленской администрации по отношению к местным землевладельцам. В дело были замешаны практически все звенья региональной администрации, включая личного ставленника М.Н. Муравьёва - гродненского губернатора Ивана Николаевича Скворцова. В документах следствия, предпринятого подполковником жандармов Козловым, говорится следующее:

[...] имение Озёры графа Валицкого приносило годового дохода от 30 до 40 тыс. руб. На это имение обратилось внимание губернатора Скворцова. Рассказывают, что фактор Вильбушевич (доверенное лицо гродненского губернатора И.Н. Скворцова) предложил графу Валицкому заплатить 50 тыс. руб. [...] и остаться неприкосновенным в деле мятежа. Граф Валицкий не согласился из упрямства и неимения в наличности капитала отчасти и потому, что считал предложение Вилбушевича чересчур бесцеремонною проделкою. Менее чем через неделю граф Валицкий был арестован, а ценная его движимость, состоявшая из бриллиантов и золота, исчезла бесследно. Говорят, что камердинер Валицкого был преведомлен и за 2 часа до обыска выехал в Гродно, где и передал шкатулку со всеми вещами в руки губернатору Скворцову ${ }^{37}$.

О личной причастности гродненского губернатора к разграблению имения Л. Валицкого свидетельствуют и другие источники, в том числе мемуарная литература. Так, Ян Биспинг в своих воспоминаниях констатировал, что

[...] имение с наилучшими коллекциями было конфисковано. Гродненский исправник Магнус и губернатор Скворцов украли самые красивые экспонаты, а в особенности табакерки, украшенные бриллиантами времен Марии Антуанетты. Был спасен только великолепный и единственный в своем роде розовый бриллиант, я видел его в Гродно в руках пани Чеховской, большого друга Валицкого, который она повелела обналичить где-то за границей, и тем самым долгие годы поддерживала сосланного друга $[\ldots]^{38}$.

Другой мемуарист, Л. Завистовский писал, что был хорошо знаком с этим делом и даже держал в руках краденные вещи. Кроме того, он считал, что действия гродненского губернатора покрывал сам М.Н. Муравьёв:

${ }^{37}$ LVIA, f. 378, ap. 1868 b/s, b. 354, 1. 15-16.

${ }^{38}$ Moje wspomnienia w Massalanach spisane. Pamiętniki Jana ordynata Bispinga 1842-1892 (Kielce: Wydawnictwo Uniwersytetu Jana Kochanowskiego w Kielcach, 2017), 139. 
[...] под конвоем Валицкого выслали в Гродно и кинули в тюрьму, а сами начали грабить - обобрали до такой степени, что не говоря о серебряных и золотых сервизах, различных табакерок с драгоценными камнями, до нитки позабирали всю одежду. Натурально, что родственники подняли шум из-за такой кражи, но Муравьев сам это все устроил через свое доверенное лицо губернатора Скворцова. Рад был он тому, что имение удалось увести в казну [...] в то время многие ценности всплывали непосредственно у губернатора Скворцова [...] своими глазами видел, как через своего фактора еврея тайно прислал один серебряный сервиз кузине Валицкого, Чеховской, однако даже сотой части не отдали, потому что офицеры гвардии вывезли с собой в Петербург, и все этим закончилось. Все это делалось публично и без малейшего стыда, совести и боязни $[\ldots]^{39}$.

Таким образом, факт разграбления Озёр и причастности к этому делу гродненского губернатора подтверждается несколькими источниками как официального, так и неофициального характера. Резонанс от этого дела дошел до столицы, в результате чего высшие власти инициировали проверку многочисленных слухов. Ответственность за ее объективное проведение была возложена на... И.Н. Скворцова.

Парадоксальность всей ситуации заключается в том, что проверкой были действительно выявлены факты хищений и даже установлены виновные, которые были отданы под суд. Но это были мелкие «сошки», чиновники, которые производили приём имения в казну. После приказа сверху летом 1864 г. гродненский губернатор делегировал жандармского офицера Джонсона в Озёры. Уже первые опросы местных жителей выявили картину масштабного грабежа. Они подробно показали, что именно было похищено из помещичьих усадеб, и кто это сделал. Основными фигурантами уголовного дела стали становой пристав Александр Григорьев и исправник Лев Могденко, которые, согласно показаниям местных жителей, вывезли:

серебрянную вроде сахарницы и на ней вычеканано кругом портреты королей, бриллиантовый портрет и мелкие деньги, старинные монеты, 6 или 8 картин в позолоченных рамках, изображающие битвы, складной матрас, 4 подушки, большой серебрнный поднос, ящик с столовой посудой и 3 мешка; 2 ландшафта (картины) медвежью шубу, тюфяки, 2 подушки, разную фарфоровую посуду хорошего достоинства, серого цвета камень, который [...] стоил 300 червонцев, черепашью шкатулку, 5 мраморных камней и кусок серого сукна, образ Божьей матери в серебряной раме и 4 картины в рамках. Накануне рождества Григорьевым и Зайцевым взяты были три стола, 2 вазы китайские, часы и белого

${ }^{39}$ Pamiętnik wygnańca z roku 1863, 7-8. 
мрамора статуя с изображением человека точащего нож, три драгоценных фарфоровых блюда, которые не были в употреблении, а служили украшением; бриллиантовый не очень большой величины круглый перстень и значительная часть денег мелкою серебряною монетою; кусок тонкого полотна [...] из которой сшили сорочки Григорьеву и его жене; в значительном количестве бывшая в погребах старая водка, а также много вин и т.д. и т.п. ${ }^{40}$

Конечно этот список неполный. Можно не сомниваться, что свою руку к имуществу Л. Валицкого приложили и другие чиновники. Например, свидетели показывали на капитана Семеновского полка Менщикова, который еще до прихода гражданских лиц устроил обыск в озёрской усадьбе с целью обнаружения «подозрительных вещей» ${ }^{41}$.

В августе 1864 г. на квартирах А. Григорьева и Л. Могденко были устроены обыски, на которых в качестве понятых присутствовали люди из службы Л. Валицкого. Во время этих действий у чиновников были обнаружены графинчик и бокальчик, которые бывший камердинер Сельванович признал за собственность Валицкого, хомут, телега, лошади, бричка, сафьяновый большого размера бумажник с бумагами Валицкого и бочонок с надписью на польском языке «наливка на рябиновом ивете с 1859 г.» объёмом примерно два ведра ${ }^{42}$. И всё. Куда делись остальные вещи, стоимость которых Л. Валицкий оценивал в 300 тыс. руб., а местные ростовщики-евреи в сумму более 200 тыс. руб. ${ }^{43}$, следствие ответа не даёт. Л. Могденко и А. Григорьев были отданы под военный суд.

Принеся этих чиновников в жертву, И.Н. Скворцов тем самым рассчитывал, в первую очередь, отвести подозрения от себя самого. С этой же целью он в своих отчетах вышестоящим органам всячески старался поставить под сомнение наличие у Л. Валицкого драгоценностей, а также адекватность последнего. В рапорте на имя виленского генерал-губернатора, датируемым 1866 г., он утверждал, что военно-следственной комиссией было обнаружено, что Л. Валицкий никогда не имел у себя дома вещей на 300 тыс. руб. Им же были разработаны несколько версий того, куда бы могла исчезнуть главная драгоценность Валицких, а именно знаменитый бриллиант. Согласно одной из них Леопольд подарил этот бриллиант во время своего сватовства девице Керножицкой из Пру-

\footnotetext{
${ }^{40}$ НИАБ в г. Гродно, ф. 1, оп. 31, д. 445, л. 5, 13-14, 19, 20, 24, 25.

${ }^{41}$ НИАБ в г. Гродно, ф. 1, оп. 31, д. 445 , л. 63.

${ }^{42}$ НИАБ в г. Гродно, ф. 1 , оп. 31, д. 445, л. $55,63$.

${ }^{43}$ LVIA, f. 378, ap. 1865 p/s, b. 630, 1. 18; LVIA, f. 378, ap. 1868 b/s, b. 354, 16.
} 
жанского уезда Гродненской губернии. По второй версии И.Н. Скворцова, все драгоценности (золото, серебро и бриллианты) были вывезены сестрой (или, скорее всего, женой брата) за день до описи имения и позже заложены у евреев в Гродно ${ }^{44}$. Об объективности подачи гродненским губернатором информации относительно Валицкого и его имущества, можно судить хотя бы по тому, как он излагает описанное выше дело «о хищении драгоценностей у Л. Валицкого». Согласно И.Н. Скворцову, в рамках дела было арестовано более ста человек (на самом деле - не больше полутора десятка), действия комиссии продолжались непрерывно около 4-х лет (на самом деле менее одного года), некоторые привлеченные к этому делу лица покончили жизнь самоубийством (единственная жертва - ксёндз А. Михаловский, который согласно заключению врачей умер у себя в квартире от «эпидемической болезни»), многие окрестные жители бежали из своих домов и т.п. ${ }^{45}$ Как видим, тут присутствует сознательное искажение фактов, с целью вызвать у вышестоящих органов недоверие как к самой личности Л. Валицкого, так и той информации, которая от него поступала. В свою очередь, верификация данных, которые приводит гродненский губернатор, позволяет нам сделать вывод, что и остальная информация относительно Озёр в 1863-1866 гг., которая исходила от этой особы, а также из гродненской канцелярии, не может считаться достоверной.

Согласно действующим правилам, после наложения секвестра имение было отдано в казенное управление, в течение которого чиновники не прекращали грабежа, на этот раз экономического. На это напрямую указывают отчеты о доходности Озёр за время нахождения в управлении казны:

$[\ldots]$ имение Езиоры, принадлежавшее гр. Валицкому [...] и попавшее после конфискации в руки Мореншильда, принесло чистого дохода 239 руб. в 18-месячный период. Ревизуя эту отчетность, контрольная палата обнаружила злоупотребления в документах по книгам, причем оказалось, что 239 руб. не есть чистый доход с имения, т.к. в цифре прихода показаны суммы, полученные от продажи рогатого скота, лошадей, овец, свиней, булыжного камня и кирпича всего на сумму около 8 тыс. руб. ${ }^{46}$

\footnotetext{
${ }^{44}$ LVIA, f. 378, ap. 1865 p/s, b. 630, 1. 10, 26.

${ }^{45}$ LVIA, f. 378, ap. 1865 p/s, b. 630, 1. 28.

${ }^{46}$ LVIA, f. 378, ap. 1868 b/s, b. 354, 1. 23.
} 
Опять же по инициативе высших властей было инициировано разбирательство по вопросу злоупотреблений, в результате чего под следствие попал бывший управляющий имением чиновник Мореншильд. Кстати, это по его инициативе в Озёрах в своё время был проведен аукцион, на котором были проданы остатки драгоценных вещей (их опись так и не была представлена) за смешную сумму в 109 руб. 96 коп. в счет погашения долгов, что успели накопиться за время пребывания в казённом управлении ${ }^{47}$. Кроме того, огромный урон имению в это время был нанесен бесконтрольной вырубкой леса, которую чиновники вместе с лесничим осуществляли под видом высечки сухостоя.

В этом плане больше повезло библиотеке Валицких. После описания имения собрание книг, старинных рукописей и грамот было свалено без всякого надзора в одном из сараев, подвергаясь порче под влиянием сырости $^{48}$. Управляющий государственными имуществами Гродненской губернии 28 апреля 1867 г. сообщил гродненскому губернатору, что в конфискованном у Валицкого имения Озёры находится до 2850 книг ${ }^{49}$, и 9 июля 1867 г. озёрская библиотека, в формировании которой принимал активное участие еще Михаил Валицкий, была вывезена в Вильно, где поступила в фонды Виленской публичной библиотеки ${ }^{50}$.

С 1865 г. имение сдавалось в аренду различным людям, которые на торгах предлагали за это право большие деньги. Например, с 14 сентября 1865 г. Озёры были отданы поручику Александру Каховскому на один год в «безотчетное администрационное управление» за 6600 руб. с правом казны по истечении этого срока устранить Каховского от администрации без всякого вознаграждения его за убытки и издержки, а само имение продать. Если же продажа не состоится, то имение могло оставаться у Каховского, если он пожелает, до трех лет ${ }^{51}$.

Имение было отдано Каховскому со всеми оброчными статьями, и он должен был отчитываться перед казной исправным содержанием имения и взносом арендных денег. Но практически сразу с выплатами возникли сложности. В начале апреля арендатор уплатил числящуюся за ним недоимку за первое полугодие и обратился с просьбой разрешить

\footnotetext{
${ }^{47}$ НИАБ в г. Гродно, ф. 1, оп. 22, д. 1438, л. 1.

${ }^{48}$ НИАБ в г. Гродно, ф. 1, оп. 22, д. 1438, л. 1.

49 НИАБ в г. Гродно, ф. 1, оп. 6, д. 783, л. 4.

${ }^{50}$ L. KowkIEL, Prywatne księgozbiory na Grodzieńszczyźnie w pierwszej połowie XIX wieku (Kraków: Wydawnictwo Naukowe Akademii Pedagogicznej, 2005), 75, 143.

${ }^{51}$ НИАБ в г. Гродно, ф. 1, оп. 14, д. 11, л. 14-14 об.
} 
передать аренду его родному брату капитану гвардейской конной артиллерии Каховскому. Передача не состоялась, поскольку капитан Каховский не проживал в Гродненской губернии и, следовательно, было сложно подтвердить его благонадежность. Нового арендатора найти не сумели (большое имение требовало значительной арендной платы), и власти озаботились скорейшим составлением проекта раздела Озёр на участки, чтобы по истечении арендного срока продать имение, согласно Высочайшему повелению 23 июля 1865 г.

Видимо раздел имения, требовавший значительных усилий местной администрации, не был произведен, и был образован один выкупной участок для продажи лицам русского происхождения, включавший 3539 десятин земли, 5407 - леса, 194 - не удобной земли, 105 построек и оброчные статьи: рыбная ловля, суконная фабрика, водяная мукомольная мельница, винокурня, пивоварня, семь корчем, три дома «с плацами» в местечке Озёры и там же 193 «плаца». Имение было оценено в 107374 руб. 60 коп. ${ }^{52}$

Прежде чем провести процедуру продажи, необходимо было удовлетворить денежные претензии частных лиц и ведомств к Леопольду Валицкому. Оказалось, что к имению было предъявлено долговых претензий на сумму 272818 руб. 26 коп. ${ }^{53}$, что в 2,5 раза превышало его стоимость. В следствии столь значительного количества значительного количества долгов, долгов, на основании Правил для ликвидации долгов и рассмотрения претензий, предъявленных к конфискованным имениям, от 26 января 1868 г., имение подлежало продаже с публичных торгов. Но и этого власти не смогли реализовать на протяжении 1860-х годов, поскольку разбор долговых исков затянулся. Многие кредиторы, которым было отказано, подавали апелляции. Окончательно судьба Озёр была разрешена в декабре 1871 г., когда они целиком были проданы генераладъютанту графу Николаю Васильевичу Левашову за 270666 руб. 45 коп. $^{54}$ Одним из условий сделки было согласие нового владельца удовлетворить признанные властями долговые претензии, лежащие на имении ${ }^{55}$.

Что же касается самого Леопольда Валицкого, то местом его поселения была избрана Верхоленская волость Иркутской губернии. О дороге Валицкого в ссылку известно немного. Видимо ему удалось захватить

\footnotetext{
52 НИАБ в г. Гродно, ф. 1, оп. 14, д. 574, л. 2.

${ }^{53}$ НИАБ в г. Гродно, ф. 1, оп. 14, д. 574, л. 2.

${ }^{54}$ НИАБ в г. Гродно, ф. 2, оп. 19, д. 13, л. 3-3 об.

${ }^{55}$ НИАБ в г. Гродно, ф. 31, оп. 6, л. 141.
} 
с собой небольшое количество наличных денег, так как значительную часть пути он проехал за собственный счет. В Тобольск Леопольд прибывает на почтовых 22 февраля 1864 г., 25 марта на подводах за собственный счет добирается до Томска, а до Красноярска - отдельно от партии 3 апреля. После недельного отдыха он отправляется на подводах за собственный счет в Иркутск, куда прибывает 18-го апреля, преодолев таким образом пространство от Тобольска до Иркутска менее чем за два месяца. В Иркутске он находился до 28 мая 1864 г. и затем был отправлен по этапу в партии пересыльных арестантов на поселение в Верхоленскую волость ${ }^{56}$.

Время прибытия нашего героя на место поселения не известно. Первым упоминанием о Леопольде в Сибири стало его письмо из Верхоленска, написанное в июле 1865 г. племяннику Михаилу Жабе, сосланному на жительство в город Курган Тобольской губернии. Л. Валицкий писал:

Знаеш о том наверно, что я никогда не надеялся подвергнутся всему этому, так безправно, и что бы могли меня судить невинно и забрать у меня всё, - однако же я не ослабеваю. Всё мое огромное состояние взято по праву сильнаго ${ }^{57}$.

Кроме Михаила, в ссылке оказался и второй сын сестры Леопольда Иоанны, состоявшей в замужестве за помещиком Дисненского уезда Иосифом Жабой, а именно Каспер Жаба. Он отбывал наказание в г. Верхотурье Пермской губернии. Вдова родного брата Михаила - Леокадия (из рода Чеховских) вместе с тремя дочерями была сослана в Воронежскую губернию. Одна из них, Людвика, вышла замуж за некого Михаила Комара и после заключения брака получила возможность вместе с матерью и сестрами вернуться на родину ${ }^{58}$. Леокадия и Мария, пока были в ссылке, поддерживали письменные контакты с Каспером, но ни Михаилу, ни Леопольду не писали. Михаил Жаба сообщал родителям,

${ }^{56}$ ГА РФ, ф. 109, 1 эксп., 1864, оп. 39, д. 265, л. 114 об., 142, 149, 211 (Информация предоставлена Анной Брус).

57 „List Leopolda Walickiego do Michała Żaby, Wiercholeńsk, lipiec 1865 r.”, w Syberyjska Korespondencja zestańców postyczniowych (1864-1866): „Po drodze życia wstapić przed śmiercia do Polski”, wybór, oprac., wstęp W. Caban, S.A. Mulina (Kielce: Wydawnictwo Uniwersytetu Jana Kochanowskiego w Kielcach, 2018), 276 (Цитируется с сохранением особенностей орфографии источника).

58 „List Michała Żaby do wuja, Kurgan. 20 października 1865 r.”, w Syberyjska Korespondencja zestańców postyczniowych (1864-1866), 205. 
что дядя ропщет в своем письме на недостаток известий от родных и знакомых и интересуется судьбой своих сестер - Иоанны и Паулины:

В письме его пробивается мужество и забвение. Утрата состояния нисколько его не сломала, - одно только его огорчает, это собственно то невнимание или непамять особ близских его сердцу, что и каждый из нас здесь испытывает, не приймите, мои милые, этого за упрек, - это голос наболевшаго сердца, которое, не видя вокруг себя никакого признака памяти, сохнет с тоски и вбивает в мысль, что быть может не заслужил привязанности ${ }^{59}$.

О жизни Леопольда Валицкого в Сибири нам известно со слов ксендза Станислава Матрася. По его свидетельству, бывший владелец Озёр пользовался уважением соотечественников. Матрась называет его «достопочтенным, благородным, настоящим польским патриотом, который был любим и уважаем всеми ссыльными поляками» ${ }^{60}$. В Верхоленске граф столкнулся с типичными для ссыльных повстанцев трудностях недостатком финансов, отсутствием возможности найти работу и скудостью интеллектуальной жизни. В письме к племяннику он отмечал: «Мы здесь живём своим кружком, имеем несколько книг; это нас только поддерживает, - не запрещают этого удовольствия, без которого не знаю, что бы делал $[\ldots]{ }^{61}$.

Сохранившиеся письма и свидетельства современников позволяют зафиксировать, как бывший граф приноравливался к новым условиям жизни. Не имея другого источника содержания, кроме казенного пособия, равного примерно 6 рублям в месяц ${ }^{62}$, Л. Валицкий сам подметал свою комнату, носил воду из колодца, рубил дрова, топил печь, но при этом держал «двух прекрасных легавых» ${ }^{63}$. Вряд ли пожилой человек со слабым здоровьем промышлял охотой, скорее всего, собаки напоминали о прежней жизни и позволяли преодолеть психологический стресс. Михаил Жаба писал в декабре 1865 г. брату Касперу:

59 „List Michała Żaby do rodziców, Kurgan, 24 kwietnia 1865 r.”, w Syberyjska Korespondencja zestańców postyczniowych (1864-1866), 183-184.

${ }^{60}$ S. MATRAŚ, Podróż do Syberii po moskiewskich etapach w 1863 i 1864 roku, oprac. i wstępem opatrzył E. Niebelski (Lublin: Werset, 2008), 151-152.

61 „List Leopolda Walickiego do Michała Żaby”, 276 (Цитируется с сохранением особенностей орфографии источника).

${ }^{62}$ Сумма складывалась из выдаваемых раз в месяц квартирных денег в размере 1 рубля 20 копеек и выплачиваемых посуточно 15 копеек кормовых.

${ }^{63}$ Matraś, Podróż po Syberii, 152. 
От Валицкаго недавно получил письмо, в котором описывает свое грустное положение в Верхоленске по случаю недостатка финансов, из своего же огромнаго состояния ничего не мог спасти. Начинаю теперь более его ценить, а в особенности за то, что не упадает духом, хотя положение его, как человека не привыкшаго к труда ${ }^{64}$, ужастно худо ${ }^{65}$.

Спустя несколько лет, благодаря стараниям влиятельных лиц, Леопольду разрешили перебраться из Верхоленска в Иркутск, где он исполнял обязанности библиотекаря польской и в то же время сибирской библиотеки ${ }^{66}$. Матрась писал, что в Иркутске поляки делились на несколько кружков, каждый из которых складывался из 5-6 или 7 человек. Кружок, к которому принадлежали Матрась и Валицкий, включал в себя семерых ссыльных, четверо из которых брали с кухни арестантские обеды и ужины, а трое брали деньги - 11 копеек, на которые покупали чай, сахар и булки для совместных завтраков. Леопольд не смог больше одной недели вынести «вонючих тюремных блюд», отдал какому-то иркутскому купцу свои золотые часы за сто рублей и с тех пор харчевался у надзирателя тюрьмы ${ }^{67}$. Сложно сказать, кто еще составлял круг общения Валицкого. Якуб Гейштор прибывший из Усолья в Иркутск на поселение, в своем блокноте указал 138 фамилий лиц, которые находились постоянно или проездом в Иркутске. Леопольда Валицкого он тоже упомянул, но это не гарантирует того, что у них были тесные контакты ${ }^{68}$. О том, что Леопольд контактировал с соотечественниками и пользовался их уважением говорит и тот факт, что 13 сентября 1870 г. он стал крестным стал кресным сыном сына ссыльного Генриха Эрнеста - Александра, родившегося в июне этого же года в селе Урик Иркутской губернии ${ }^{69}$.

В апреле 1869 г. после выхода очередного царского манифеста, Валицкий получил разрешение выехать из Сибири в одну из губерний Европейской России ${ }^{70}$. Но финансовые проблемы не позволили воспользоваться этим правом. «Бедный пан Леопольд Валицкий не может

\footnotetext{
${ }^{64}$ Так в документе. Правильно: труду.

${ }^{65}$ „List Michała Żaby do brata Kaspra Ignacego Przyłuskiego, Kurgan, 4 grudnia 1865 r.”, w Syberyjska Korespondencja zestańców postyczniowych (1864-1866), 208 (Цитируется с coxpaнением особенностей орфографии источника).

${ }^{66}$ Matraś, Podróż po Syberii, 152.

${ }^{67}$ Matraś, Podróż po Syberii, 153.

${ }^{68}$ W. ŚliwowsKa, Syberia w życiu i pamięci Gieysztorów - zesłańców postyczniowych. WilnoSybir - Wiatka - Warszawa (Warszawa: Wydawnictwo DiG, 2000), 72, 355.

${ }^{69}$ Национальный исторический архив Беларуси (НИАБ), ф. 1781, оп. 36, д. 120, л. 68 об.

${ }^{70}$ ГА РФ, ф.109, 1 эксп., 1867, оп. 42, д. 55, л. 259-260, 275.
} 
двинуться из-за недостатка средств» - писал ссыльный ксендз Юзеф Калиновский из Иркутска 17 февраля 1872 г. Якубу Гейштору ${ }^{71}$.

В 1875 г. Леопольд Валицкий все еще проживал в Иркутске, на улице Большой (ныне - ул. Карла Маркса), в доме купца Полуектова. В марте 1875 г. иркутское губернское правление известило местного полицмейстера, что император Александр II разрешил применить к Валицкому 3-й пункт Всемилостивейшего повеления 13/17 мая 1871 г. и выдать вид на свободное проживание по всей Российской империи, за исключением столиц, столичных губерний и Западного края ${ }^{72}$. Но и на этот раз ему не удалось покинуть Сибирь. Властям Леопольд объяснял, что не может выехать, потому что занят устройством собственных дел ${ }^{73}$. Можно предположить, что Леопольд не спешил с отъездом, поскольку пытался списаться с родственниками, которые могли бы принять уже немолодого человека под свою опеку. На роль такого товарища, готового протянуть руку помощи, более всего подходил Михаил Жаба, который к этому времени уже был освобожден от полицейского надзора и проживал в Верхотурье вместе с братом Каспером. Не известно, как развивались бы события дальше, но 16 июня 1875 г. Леопольд Валицкий в возрасте 61 года скончался от «апоплексии мозга» и 18 июня был похоронен викарным священником Францем Скобейко на иркутском кладбище ${ }^{74}$.

В польской мемуаристке и литературе встречаются другие даты смерти Валицкого, вызывающие меньше доверия, чем информация, зафиксированная в метриках иркутского костела. Вот, например, что пишет Станислав Матрась:

В 1876 году, в августе месяце, когда я жил второй раз в Иркутске, граф Валицкий пригласил к себе в одно из воскресений несколько знакомых поляков на преферанс. Во время чая он получил апоплексический удар и неожиданно закончил свою изгнанническую жизнь ${ }^{75}$.

Таким образом, судьба Леопольда Валицкого формировалась под влиянием политической обстановки в Западном крае и была тесно связана с состоянием дел в имении. До получения наследства Валицкий реали-

\footnotetext{
${ }^{71}$ A. KUCZYŃSKI, Syberia. 400 lat polskiej diaspory (Wrocław: Atla 2, 1998), 243.

${ }^{72}$ Государственный архив Иркутской области (ГАИО), ф. 91, оп. 1, д. 159, л. 1а-1а об.

${ }^{73}$ ГАИО, ф. 91, оп. 1, д. 159, л. 3.

${ }^{74}$ ГАИО, ф. 297 , оп. 1 , д. 86 а, л. 4.

${ }^{75}$ Matraś, Podróż po Syberii, 152.
} 
зовывал жизненный путь типичного безземельного шляхтича, зарабатывающего канцелярской работой. После получения наследства, он становится влиятельной личностью в губернии и практически сразу попадает в поле зрения властей, даже будучи далеким от политики. Доходное имение привлекает многочисленных охотников до легкой наживы, начиная от обедневших родственников, до представителей местной чиновничьей верхушки, которая была не прочь использовать государственные интересы в корытных целях. Дело Валицкого показывает, что передел земельной собственности в Западном крае в пользу русского землевладения сопровождался ростом злоупотреблений чиновничества и хищнических амбиций местной бюрократической верхушки. Управленческий аппарат был не в состоянии справиться со свалившимися на него задачами, а попавшие под секвестр и конфискованные имения местной шляхты приходили в упадок.

Сибирская жизнь Валицкого демонстрирует нам типичную историю ссылки участника восстания 1863 г., терпевшего нужду, тосковавшего по родным и близким, а, с другой стороны, дает интересный антропологический материал, показывая, как привыкший к роскоши дворянин адаптируется к жизни изгнанника, обустраивает быт, восстанавливает круг общения и, по всей видимости, сомневается в необходимости возвращаться на родину.

\section{БИБЛИОГРАФИЯ}

\section{АРХИВНЫЕ ИСТОЧНИКИ}

Lietuvos valstybès istorijos archyvas (LVIA)

f. 1219 , ap. 1, b. 687 ;

f. 378 , ap. 1865 p/s, b. 630 ;

f. 378 , ap. 1868 b/s, b. 354 .

Gosudarstvennyj arhiv Rossijskoj Federacii (GA RF) [Государственный архив Российской Федерации (ГА РФ)]

ф. 109, 1 эксп., 1863, оп. 23, д. 416 [f. 109, 1 jeksp., 1863, op. 23, d. 416];

ф. 109, 1 эксп., 1864, оп. 39, д. 265 [f. 109, 1 jeksp., 1864, op. 39, d. 265];

ф.109, 1 эксп., 1867, оп. 42, д. 55 [f.109, 1 jeksp., 1867, op. 42, d. 55].

Gosudarstvennyj arhiv Irkutskoj oblasti (GAIO) [Государственный архив Иркутской области (ГАИО)]

ф. 91, оп. 1, д. 159 [f. 91, op. 1, d. 159];

ф. 297 , оп. 1, д. 86 а. [f. 297, op. 1, d. 86 a].

Nacional'nyj istoricheskij arhiv Belarusi (NIAB) [Национальный исторический архив Беларуси (НИАБ)]

ф. 1781 , оп. 36, д. 120 [f. 1781, op. 36, d. 120]. 
Nacional'nyj istoricheskij arhiv Belarusi v g. Grodno (NIAB v g. Grodno) [Национальный исторический архив Беларуси в г. Гродно (НИАБ в г. Гродно)]

ф. 1, оп. 14, д. 574 [f. 1, op. 14, d. 574];

ф. 1, оп. 22, д. 1438 [f. 1, op. 22, d. 1438];

ф. 1, оп. 22, д. 1456 [f. 1, ор. 22, d. 1456];

ф. 1 , оп. 28 , д. 655 [f. 1 , op. 28 , d. 655];

ф. 1 , оп. 29 , д. 108 [f. 1, op. 28, d. 108];

ф. 1 , оп. 31 , д. 445 [f. 1, op. 31, d. 455];

ф. 1 , оп. 34 , д. 3420 [f. 1, op. 34 , d. 3420];

ф. 1 , оп. 4 , д. 123 [f. 1, op. 4, d. 123];

ф. 1, оп. 5, д. 1666 [f. 1, op. 5, d. 1666];

ф. 1 , оп. 5 , д. 1798 [f. 1 , op. 5, d. 1798];

ф. 1, оп. 6, д. 783 [f. 1, op. 6, d. 783];

ф. 2, оп. 19, д. 13 [f. 2, op. 19, d. 13];

ф. 2, оп. 4, д. 1678 [f. 2, op. 4, d. 1678];

ф. 31, оп. 6, л. 141 [f. 31, op. 6, d. 141];

ф. 332, оп. 3, д. 1 [f. 322, op. 3, d. 1];

ф. 96, оп. 1 , д. 65 [f. 96, op. 1, d. 65].

Zhurnal Ministerstva narodnogo prosveshhenija, shestoe desjatiletie, ch. CCXLVIII. SPb. 1886, nojabr' [Журнал Министерства народного просвещения, шестое десятилетие, ч. CCXLVIII. СПб. 1886, ноябрь].

\section{ЛИТЕРАТУРА}

ANFIMOv, Andrej Matveevich. Krupnoe pomeshhich'e hozjajstvo Evropejskoj Rossii (konec XIX nachale XX veka). Moskva: Izd-vo "Nauka" 1969 [Анфимов, Андрей Матвеевич. Крупное помещчичье хозяйство Европейской России (конеи ХІХ - начале XX века). Москва: «Изд-во Наука», 1969].

Bulgarin, Faddej Venediktovich. Vospominanija Faddeja Bulgarina: Otryvki iz vidennogo, slyshannogo i ispytannogo v zhizni, [v 6 ch.], ch. 1-2. SPb.: tip. Eduarda Pracza, 1846 [БУлГАРИН, Фаддей Венедиктович. Воспоминания Фаддея Булгарина: Отрывки из виденного, сльшанного и испытанного в жизни, [в 6 ч.], ч. 1-2. СПб.: тип. Эдуарда Праца, 1846].

DASZKIEwICZ, Piotr, SAMOJLIK Tomasz, KRASIŃSKa Małgorzata. „Leopold Walicki’s Experiments on Cross-Breeding European Bison with Cattle in the Context of $19^{\text {th }}$ century Biological Sciences”. Историко-биологические исследования 4, № 1 (2012): 33-40 [Istoriko-biologicheskie issledovaniya 4, $\mathrm{nr} 1$ (2012): 33-40].

FEDORUK, Anatolij Tarasovich. Starinnye usad'by Grodnenshhiny: Berestovickij rajon, Volkovysskij rajon, Voronovskij rajon, Grodnenskij rajon, Djatlovskij rajon, Zel'venskij rajon, Iv'evskij rajon. Minsk, 2014 [ФЕдорук, Анатолий Тарасович. Старинные усадьбы Гродненщины: Берестовиикий район, Волковысский район, Вороновский район, Гродненский район, Дятловский район, Зельвенский район, Ивьевский район. Минск, 2014].

Genlis DE, Stéphanie Félicité. Cudowny szafir czyli Talizman szczęścia: powiastka wschodnia, przeł. i oprac. J. Raźny, aneksem opatrzył W. Pusz. Łódź: Oficyna Wydawnicza Tercja, 2008.

Grodnenskie gubernskie vedomosti 1906 [Гродненские губернские ведомости 1906].

KowKIEL, Lilia. Prywatne księgozbiory na Grodzieńszczyźnie w pierwszej połowie XIX wieku. Kraków: Wydawnictwo Naukowe Akademii Pedagogicznej, 2005.

KuCZYŃSKI, Antoni. Syberia. 400 lat polskiej diaspory. Wrocław: Atla 2, 1998. 
MatraŚ, Stanisław. Podróż do Syberii po moskiewskich etapach w 1863 i 1864 roku, oprac. i wstępem opatrzył E. Niebelski. Lublin: Werset, 2008.

Moje wspomnienia w Massalanach spisane. Pamiętniki Jana ordynata Bispinga 1842-1892, oprac. J.Z. Pająk, J. Szczepański. Kielce: Wydawnictwo Uniwersytetu Jana Kochanowskiego w Kielcach, 2017.

Pamiętnik wygnańca z roku 1863. Spisał z własnych przeżyć (Lucjan) Zawistowski, tekst oprac., wstępem i przypisami opatrzyli W. i M. Wójcikowie, przedmowa W. Caban. Kielce: Instytut Filologii Polskiej Uniwersytetu Jana Kochanowskiego w Kielcach, 2015.

Powstanie styczniowe i zesłańcy syberyjscy. Katalog fotografii ze zbiorów Muzeum Historycznego m.st. Warszawy. Część II. Zesłańcy syberyjscy, oprac. E. Kamińska. Warszawa: Muzeum Historyczne m.st. Warszawy, 2005.

RuZVEL'T, Priscilla. Zhizn'v russkoj usad'be: opyt social'noj i kul'turnoj istorii, per. s angl. N.A. Voznesenskogo, A.V. Voznesenskogo. SPb.: Kolo, 2008 [РузвЕльт, Присцилла. Жизнь в русской усадьбе: опыт соииальной и культурной истории, пер. с англ. Н.А. Вознесенского, А.В. Вознесенского. СПб.: Коло, 2008].

SAMUSIK, Andrej Fiodaravič. Hraf Michal Valicki - ajčynny kaliekcyjanier i miecenat druhoj palovy XVIII - pieršaj čverci XIX st.”. V Hrodna i hrodziency: dzieviać stahoddziaŭ historyi (da 880-hoddzia horada): materyjaly Mižnar, navuk. kanf., Hrodna, 10-11 kras. 2008 h., navuk. red. I.P. Kreń, 416-420. Hrodna: HrDU, 2008 [САмуСІк, Андрэй Фёдаравіч. „Граф Міхал Валіцкі - айчынны калекцыянер і мецэнат другой паловы XVIII - першай чвэрці XIX ст.”. В Гродна і гродзенщьл: дзевящьь стагоддзяў гісторыі (да 880-годдзя горада): матэрыялы Міжнар, навук. канф., Гродна, 10-11 крас. 2008 г., навук. рэд. І.П. Крэнь, 416-420. Гродна: ГрДУ, 2008].

SORKINA, Ina. Miastečki Bielarusi $\breve{u}$ kancy XVIII - pieršaj palovie XIX st. Viĺnia: Euurapeiiski humanitarny universitet, 2010 [СОРКІнА, Іна. Мястэчкі Беларусі ў канцы XVIII - периай палове XIX cm. Вільня: Еўрапейскі гуманітарны універсітэт, 2010].

STRZYŻEWSKI, Wojciech. „Wstęp”. W Szlachta europejska w strukturach lokalnych XVI-XVIII wieku, red. nauk. M. Konopnicka, J. Kuczer, W. Strzyżewski. Zielona Góra: Oficyna Wydawnicza Uniwersytetu Zielonogórskiego, 2010.

Syberyjska Korespondencja zestańców postyczniowych (1864-1866): „Po drodze życia wstapić przed śmiercia do Polski”, wybór, oprac., wstęp W. Caban, S.A. Mulina. Kielce: Wydawnictwo Uniwersytetu Jana Kochanowskiego w Kielcach, 2018.

ŚLIwOwSKA, Wiktoria. Syberia w życiu i pamięci Gieysztorów - zesłańców postyczniowych: Wilno Sybir - Wiatka - Warszawa. Warszawa: Wydawnictwo DiG, 2000.

Wspomnienia: Nowogródek, więzienie - wygnanie. Przez Edwarda Pawłowicza. Lwów: Drukarnia E. Winiarza, 1887.

ZANEVSKIJ, Sergej Viktaravich. „Shljahetskij rod Valickih v istorii Grodno”. V Hrodna i hrodziency: dzieviać stahoddziaŭ historyi (da 880-hoddzia horada): materyjaly Mižnar. navuk. kanf., Hrodna, 10-11 kras. 2008 h., navuk. red. I.P. Kreń, 420-425. Hrodna: HrDU, 2008 [ЗАнЕВСКИй, Сергей Виктаравич. „Шляхетский род Валицких в истории Гродно”. В Гродна і гродзенщы: дзевящь стагоддзяў гісторыі (да 880-годдзя горада): матэрыяль Міжнар, навук. канф., Гродна, 10-11 крас. 2008 г., навук. рэд. І.П. Крэнь, 420-425. Гродна: ГрДУ, 2008]. 


\section{ШЛЯХТА ЗАПАДНОГО КРАЯ В ПОЛИТИКЕ РОССИЙСКОЙ ИМПЕРИИ ВО ВТОРОЙ ПОЛОВИНЕ ХІХ ВЕКА: ЛЕОПОЛЬД ВАЛИЦКИЙ И ЕГО ИМЕНИЕ ОЗЁРЫ}

\section{А н но т а ци я}

В статье рассматривается политика царизма по отношению к привилегированному сословию Западного края на примере биографии помещика Гродненской губернии Леопольда Валицкого. Его судьба формировалась под влиянием политической обстановки в регионе и была тесно связана с судьбой имения Озёры. Сначала Валицкий реализовывал жизненный путь типичного безземельного шляхтича, зарабатывающего канцелярской работой, и только после получения наследства стал влиятельной личностью в Гродненской губернии. Большое имение, обширные родственные связи, влияние на местное население - все это способствовало повышенному вниманию властей к фигуре Валицкого. Будучи далеким от политики, он был осужден за участие в восстании 1863 г. и сослан на поселение в Иркутскую губернию. Судьба конфискованного у Валицкого имения Озеры показывает, что передел земельной собственности в Западном крае в пользу русского землевладения сопровождался ростом злоупотреблений чиновничества и хищнических амбиций местной бюрократической верхушки. В результате масштабной акции по секвестированию и конфискации имений местной шляхты, многие земельные владения пришли в упадок.

Ключевые слова: сибирская ссылка; восстание 1863 г.; шляхта; Леопольд Валицкий; политика России в Западном крае; имение Озёры.

\section{SZLACHTA ZACHODNIEGO KRAJU W POLITYCE IMPERIUM ROSYJSKIEGO W DRUGIEJ POŁOWIE XIX WIEKU: LEOPOLD WALICKI I JEGO MAJĄTEK JEZIORY}

\section{Streszczenie}

W artykule analizowana jest polityka caratu wobec uprzywilejowanej grupy społecznej ziem zabranych na przykładzie biografii ziemianina Leopolda Walickiego z guberni grodzieńskiej. Jego życiowa droga była zdeterminowana przez sytuację polityczną w kraju i złączona z losem jego majątku Jeziory. Podobnie jak większość drobnego ziemiaństwa, Walicki na początku swojej kariery realizował się w służbie państwowej i dopiero po otrzymaniu spadku znacząco zmienił się jego status bytowy. Rozlegle dobra, rodzinne skarby, wpływ na lokalną społeczność - wszystko złożyło się na to, że jego osobą szczególnie interesowały się władze rosyjskie. Mimo że był osobą apolityczną, Leopold został skazany za udział w powstaniu styczniowym i zesłany do guberni irkuckiej, a jego majątek skonfiskowano. Proces przejęcia Jezior przez skarb państwa świadczył o tym, że zmiana formy własności łączyła się ze wzrostem korupcji i różnych nadużyć ze strony cywilnej i wojskowej administracji carskiej. W wyniku konfiskaty i sekwestracji majątków uczestników powstania wiele tych gospodarstw zostało zrujnowanych.

Słowa kluczowe: zesłanie syberyjskie; powstanie styczniowe; szlachta; Leopold Walicki; polityka rosyjska na terenie ziem zabranych; majątek Jeziory. 


\section{THE GENTRY OF THE WESTERN REGION IN THE POLICY OF THE RUSSIAN EMPIRE \\ IN THE SECOND HALF OF THE XIX CENTURY: LEOPOLD VALITSKY AND HIS ESTATE OZIORY}

S u m m a r y

The article deals with the tsarist's policy towards nobility of Empire's Western region on the example of the landlord Leopold Valitski from Grodno governorate. His fate was determined by the political situation in the region and closely intermingled with the fate of his estate Oziory. Valitski, as the majority of landless nobility, started his career as a clerk and only after coming into fortune had become an authoritative person in Grodno governorate. Large estate, broad circle of kin relations, high position in local society - all these factors made Leopold an object of particular attention of Russian authorities. Being absolutely apolitical he has been convicted of participating in uprising of 1863 and exiled into Siberia. The authors in slightly details investigate Oziory confiscation process and come to the conclusion that private property seizure by the government was followed by corruption and robbing of many estates by civil and military administration. In the result of wide scale sequestration and confiscation local gentry property lots of estates fell into decline.

Keywords: Siberian exile; uprising of 1863; gentry; Leopold Valitski; Russian policy in Western region; estate Oziory. 